\title{
An Interview with Colin and Kathryn Harrison
}

Two young writers meet at the Iowa Writers' Workshop and fall in love. He is from Haverford, and she is from Stanford, and they are both very talented. They graduate and move to New York City and take jobs in publishing-he at Harper's Magazine, she at Viking. But they are writers, and they continue to write. By the time they are in their early forties, he has published five novels, all while working full-time as a salaried employee, and is now a Vice President and Senior Editor at Scribner; she has written six novels, two books of essays, a biography of St. Thérèse of Lisieux, and a travel book. This improbable narrative does not sound at all like a novel by either Kathryn or Colin Harrison, but it is a loose summary of their life story thus far.

Kathryn Harrison's novels are: Thicker Than Water, Exposure, Poison, The Binding Chair, The Seal Wife, and Envy. She has also written a bestselling memoir, The Kiss. Her personal essays have appeared in The New Yorker and elsewhere, and they are collected in Seeking Rapture and The Mother Knot. Colin Harrison is the author of five novels: Break and Enter, Bodies Electric, Manhattan Nocturne, Afterburn, and The Havana Room.

I met the Harrisons for a late brunch-fruit, bagels, and hot coffee-on a Sunday in their four-story brownstone in Brooklyn, where they live with their three children.

Joe David Bellamy: I ran across this statement over the weekend. You probably can't guess who said it: "A story must be exceptional enough to justify its telling. We storytellers are all ancient mariners and none of us is justified in stopping wedding guests unless he has something more unusual to relate than the ordinary experiences of every average man and woman." I think that admonition applies to your novel, Afterburn, Colin, and to all your work, and I believe you've taken that advice seriously.

Colin Harrison: Well, we're busy people, all of us, and as writers, the promise is that if you, the reader, take some time out to read my 
book that it'll be worthwhile and the time will be well spent, and I like to think that a writer makes a big bet to his readers early on in a book and the bet is: "Stay with me a while and I will fascinate you and tear you apart and put you back together again and turn your head inside out and do things to you that you didn't know could be done; and you're going to live to tell the tale-or remember the tale." I call that putting gold on the table or making a big bet early in a book so that the reader has the sense of an amazing, enormous story coming at him or her. So I absolutely agree with that-I'm curious to know who wrote it.

JDB: Thomas Hardy.

Kathryn Harrison: That's from the reader's point of view, but there's also the pressure to tell. What do you have to say? I mean what do you have to say? What story is providing the pressure so that it needs to be expressed?

JDB: One of the old-fashioned ideas about the short story is that it is and should be about the very ordinariness of life. I wonder if it's possible anymore to write stories about the ordinariness of life? Or novels?

Kathryn: Yeah, well, who would be doing that?-you mean like a Ray Carver story? Would that be about the ordinariness of life? Not really. I mean, it looks like it's ordinary, but you're quickly taken to the mysterious heart of something.

Colin: I think a story is what happened after which everything is different for the particular people, the characters, in the story. It may be that things are only subtly different, but things are different. I just read a story by the writer Jennifer Egan a few days ago and it's only six pages long, and it's a story of two women in their forties, both of whom have lived fast and hard lives from their twenties. Both are clearly very beautiful and in a certain crowd. There's a lot of money and drugs and everything, and they go back and they visit the very charismatic and sexy, powerful man who they've both been involved with fifteen or twenty years prior. Now he's an old man, dying. And in six pages that whole interaction becomes enormous 
in the life of the narrator who hasn't had any children. The other woman has. The narrator's life has gotten smaller since then, and the other woman has been fine and done well and I don't know-is that a regular event in a person's life? I don't know. I'm not sure.

JDB: Sounds large to me.

Colin: Yeah.

JDB: How do you decide if your material is large enough?

Kathryn: I think it has to do with how passionate you are about it yourself. There can be huge stories that are told so badly that they become nothing, flat, small; and there can be small stories that are told so deeply that they're huge. So a lot of it has to do with the vision of the person telling the story, I think. That would be true in a Ray Carver story-they seem very small and ordinary. You know, a guy sits at a counter in a diner and talks to the guy sitting next to him, and suddenly his whole life is unfolded in a way that is monumental, and yet it has a very simple workaday feel as far as the props of the story go.

Colin: When I'm writing, I look for a character who is large enough and problematic enough that I'm very interested in who that character is and what that character is going to become. In the book I'm working on now, I have a very dynamic guy who's about to buy a building in New York City, and I don't know what the connection is, but I know that at some point, not too many years ago, he was flat on his back-he'd lost all his money-he'd been swindled and choked off, and the only job he could get was supervising the pouring of concrete in elevator shafts in motels being built in New Jersey. It was almost a death sentence if you're a general contractor. I mean he had been busted down to nothing. And I also know that he has designs or involvement with a very upper-class high professional, New York City family that has a child who is about the age his daughter perhaps could be. So between those two things I know I've got something-I don't know how it all connects. But I've got these pictures in my mind of different parts of the story. I agree with Kathy that a small story can be enormous if told with density 
and passion, but also that if there's an almost sociological spread to the situation, you're going to be able to cut through a lot of social situations or places and times and people that will avail you of a huge story.

Also, I think making a big story is just a matter of assigning yourself the authority to do it. In my last book there's an interaction between characters in a parking garage in New York City, and it doesn't have to be complicated. It can be as simple as the guy handing him a ticket, and so forth; but I was interested in the fact that a lot of parking garages in New York City are down under the ground, and they're really foul places, and they're also hidden and the farther you go down under the ground, the better the cars get. Hummers and Mercedes and Jaguars. They become vaults almost. So I got sociologically interested in this, and I detoured into the material-something that people are curious about.

Kathryn: Well, yeah, you're talking about all those impulses to follow your instincts-I mean, you don't know what you're writing when you begin. You're writing to find out the ending as much as the reader is reading to find out the ending.

JDB: Colin knows about parking garages and he knows about elevator shafts. I already know that from reading his other books. [Colin and Kathryn smiling.] So he has some knowledge that goes along with his curiosity-he's imparting that as well as the story. So he's using what he knows, but, in spite of that, you still write to discover the story-both of you? I mean, is that part of the way you always go about it?

Kathryn: Yeah, I think that's a fair description of it.

Colin: I do research. There's a lot I don't know, and I make sure I find out about it if I'm going to write about it.

JDB: That's one of my questions too. I was thinking about your China book, The Binding Chair, Kathryn, which obviously involved a lot of research, and the jet scenes in Colin's Afterburn. I mean, Colin, I assume you weren't a Vietnam War pilot and so those scenes must have all been researched, and yet they're so real. And now you tell 
me it's all made up! I mean it's all just research. How can you do that? How much research do you have to do to get that kind of authority?

Kathryn: That's a very curious thing. I remember reading an interview with Mona Simpson on her second novel, The Lost Father, and there's a section that took place in Egypt and somebody said, "Well, you must have gone there," and she said, "Oh, yeah, afterwards." And I've done that too-written it and then gone-afterwards-to make sure that I hadn't messed up in some important way. The authority doesn't necessarily come from having done all the research.

JDB: It's more a matter of following your own vision-

Kathryn: Yeah, exactly, it's weird-it's chutzpah in a way.

Colin: You're lying! You're a liar.

Kathryn: Yeah.

Colin: You are lying convincingly. Part of the pleasure in writing it is knowing that you can get away with a lie, and the lie in my case is that I was a fighter pilot. How can I possibly presume to know what goes through the head of a jet fighter pilot in Vietnam twenty-seven or twenty-eight years ago? Well, I'm going to do it.

Kathryn: It's like a dare.

JDB: Are you worried at all, Colin, about what might happen if a jet pilot reads the novel—what he's going to think about it?

Colin: Well-I had a jet pilot read it-to make sure that I hadn't gotten anything grossly wrong. I was depending upon accounts written by pilots. Now the accounts themselves tended to be highly technical and not very interesting from a storytelling point of view. So I was trying to suck out the detail that I could use and, you know, I'm sure there are mistakes in there, but the idea is to perform the story-on paper. I mean, this is something that we don't always hear enough about, but when you're writing a story for someone 
else, it is a performance, just in the same way that a professional singer is singing or an actor is acting-it's a projection. It's not about you-it's about this hologram or this surface-this thing that you make in front of yourself-outside yourself. And it's sort of "method" writing. You learn and then you go up there and, in a sense, you say, "I know what I'm talking about and I'm going to make you believe me. You don't have any reason to believe me, but I will make you believe me." It's a magic trick.

Kathryn: Another thing I think is that experience is incredibly suggestive, so that, you know, two people go to Paris and both write what Paris is. One writes: "Paris is a grey city-it's incredibly depressing." The other writes: "Paris is a delight-the sun shined the entire time." You know, the landscape is a projection of the interior of the character so that you do actually have a great deal of leeway if you take the authority. So it is possible to write with authority and to create a completely credible text based on smoke and mirrors if you have some passion behind it.

JDB: When you do a contemporaneous book like Exposure, Kathryn, even if you're making some of it up, you're there so there's probably not as much research involved, that's for sure. If you're writing about New York City, there's not as much research involved.

Kathryn: Although in that case, one of the characters was someone who took wedding videos, which of course is a booming industry now. But ten years ago it was in its infancy and I ended up-I used my middle name, Elizabeth, and called up videographers who did weddings and said, "Hello, my name is Elizabeth Harrison and I'm getting married in six months and I understand that you make wedding videos and I wonder if you have any that you could show me so I could see your work." I got a bunch of wedding videos that were very useful to me. Elizabeth Harrison never got married-she never existed-but she did serve the purposes of research for me.

Colin: My feeling about this is that it's part of writer's or novelist's license. If you're a writer, at some level I think you're a criminal. No really, and I'll explain what I mean by that. You're a criminal in the sense that you are only obligated to tell the story as best you under- 
stand it, and you're obligated to no one else. You're not obligated to your parents. You're not obligated to what is polite in society. You're not obligated to make friends or keep friends. You are simply obligated to the story, and in the making of the story you often have to "steal" things. You are stealing the gold from other people's lives. It may only be that you're sitting on a park bench and you watch an old man stumble across the grass in front of you. He stumbles and he catches himself and then breathes and then continues on his way. But you've seen that, and you take that and ingest it, and you may use it at some point. It's yours. You took it. And there are other confidentialities that you may appropriate. Of course, you do not want to render particular people in a way that is identifiable. [Kathryn chuckles.] But you have an obligation to take this stuff and use it, and the thing is you steal all this now, but you give it back when you write your story or your book. It goes back out to the reader. So in that respect, doing research or posing as someone who needs a videographer, sure, you do whatever is necessary.

Kathryn: Nothing is sacred.

Colin: Nothing is sacred. And Kathryn, for one of her books, tried to figure out how to steal a diamond from Tiffany's.

Kathryn: Oh, yes, for that same book-Exposure. The heroine sort of cracks up at the end and actually contemplates stealing a ring from Tiffany's, which I think is actually, probably, impossible. But I spent a lot of time in Tiffany's figuring out how somebody would try to do that. In fact, it was interesting because I got smarter about doing it. The first time I went I was wearing jeans and sort of a scruffy shirt, and I came in and asked a stupidly naive question such as, "What would happen if somebody tried to steal a ring from Tiffany's?" Well, you know, I was escorted out of the store! Yeah. And I came back about two weeks later and I-

Colin: You were dressed up!

Kathryn: I was dressed up, and I was wearing some of my grandmother's jewelry-a couple of diamonds-and all I did was pretend to be interested in buying an estate piece. And the same woman 
who'd thrown me out of the store before...she looked at me and there was something that passed across her eyes like, "Why do I think I know this woman," but I saw it pass and then sort of disappear, and then she went on with the process. Being in the store for an hour, pretending to be confused about which piece of jewelry I might want to buy, I learned a lot about how Tiffany's works.

Colin: In my last book, I had to figure out how to convert an electronic form of money-namely, an electronic transfer-to a physical item that was fungible, sellable in a marketplace. And it was not gold, which was too heavy, and it was not any of the usual things. And I was really quite stuck. It just so happens that I know this old guy, who has this office in a building not too far from where I work, who is almost a crook. [Kathryn laughing.] He does legal things, but he also sort of does illegal things. He tries to sort of swindle the government of Bolivia by selling them expired pharmaceutical supplies and things like this, and he's an absolutely fascinating guy.

Kathryn: That qualifies him as a total crook actually.

Colin: But, anyway, so I went to him —I had lunch—and I said, "You know, Roberto, how would you-how could this be done?" And he said, "No problem. This is how you do it. You get a bill of lading and you go down to the Port of Newark, New Jersey, and you have to bribe the dock cooper, and they break open the shipping container and they get the stuff out and...." He knew exactly how to do it. And I said, "Well, what happens if...hmm-hmm-hmm," and he said, "You don't do that because then-you're dead! You do that and you're caught." He knows-he's done it. He's been involved in grey market cigarette smuggling and so on. So I found out, and that was fine.

Kathryn: Colin has a whole file of these people in his head that he can consult for various things.

JDB: I wonder if it's not true that novels are primarily about bad behavior and-

Kathryn: Transgressions. 
JDB: Yeah, transgressions.

Colin: They have to be, because if people do nothing but wonderful, good things, that's not very interesting.

Kathryn: One of my very favorite novels is Madame Bovary. I think it's a really remarkable piece of work because Emma is not an admirable woman. She's not someone we even particularly like, and yet I find her incredibly moving, her hunger as a human being. She just wants-she's alive and she wants. For some reason, she cannot fake happiness in her marriage and in her child. She's always wanting more, and she gets in this terrible sort of tangle of transgressions with the shopkeeper and with her lovers. There is this ravenous quality to her that I think is deeply human. We read it and we may not be going out and cheating on our spouses. We may not be going into hideous debt, and yet we understand the desire that she suffers. We understand her misery. So I think there is a deep identification, because sometimes the character is transgressing in a way that we have, or sometimes it's in a way that we feel we might.

Colin: I think part of the illusion is to make the reader into the character. In this last novel, one of the main characters is a woman who has been in prison because she helped her boyfriend with a truck-smuggling operation. If I can turn you, for a moment, into her.... If I can get you, the reader, for a moment, to forget you are who you are-and you always pay your quarter when you park in a parking meter, and you write thank-you notes to your grandmother, and you brush your teeth every night, and you're a decent, regular, law-abiding citizen-if I can get you to forget that and to inhabit her and her crooked little world and her crooked little philosophy, for even a little while, you're gonna like that. That's why we read. You want to become that character, to see it and feel it. That's why we read-to be out there, outside ourselves. And yet, strangely enough, to go through the action, the fall, the rise, the tragedy, that the characters go through, and that somehow comes back to you and you think, "That's what happens to people who...hmm," or "That's what happens when you want...hmm." 
Kathryn: I think maybe all successful fiction is sort of voyeuristic in essence. You know that there is this moment when you see into another person's heart, their mind, maybe even their soul, and you feel you know that person in a way that is sort of illegal. The novelist opens a window, and suddenly you can access the innermost, private core of another human being.

Colin: In the novel, at this late date, you can still do things that none of the other media can do. I'm here to tell you that. I know we have the Internet and we have television and the movies and everything, but whether the book is finally an electronic book or a book printed on paper-it really doesn't matter-the novel can still do things better and will always be able to do things better. You can go further in a book; you can tell stories that are tremendous.

JDB: Well, certainly this strong reliance on point of view is part of what you both do so well. There's no omniscience, in particular, in Afterburn. There are three points of view, rotated, and the dates.

Colin: Right.

JDB: It's an interesting way of structuring the book, which both helped me orient myself and coaxed me onward in the reading of it. I kept going back to the beginning to locate what date it was and trying to figure out what could possibly be happening on some future date. I assume that structure was something you came to after you were already in the middle of it, rather than imposing it from the beginning?

Colin: Well, I knew I was going to tell a three-person point-of-view weave, but if I was going to be cutting back and forth between three characters I had to provide a way for the reader to navigate through the story; and I also knew that if I simply had the dates and the places that that in itself would be intriguing to a reader, and I would get some forward pull that way.

JDB: In your new book, how did you get the idea in the first place about pouring cement shafts for elevators and motels? There's going to be a body. There's going to be a body in the concrete, right? 
Colin and Kathryn: [Laughing.]

Colin: I don't know actually. I'll tell you where some of it came from. I tend to talk to a lot of people-almost in a reportorial kind of way. In the case of that material, I happened to be sitting at a dining room table with a guy, much older than me, who has had a career as a builder out in New Jersey; and he told me the whole story of his life, which involved becoming rich, and then getting overextended and having interest rates cut against him in the seventies, and getting in trouble, and then as a last-ditch effort going out to Phoenix, which was a boom town, and trying to swing some deals and then getting screwed, basically, by another guy-and losing everything. This was a guy with four children, and he was busted down so far that he was pouring cement and supervising the pouring of concrete in elevator shafts. As soon as he said those words--"pouring concrete in elevator shafts in motels in New Jersey"-this thing went off in my head.

Kathryn: The knowledge buzzer! [Laughter]

Colin: Yeah, the big tapes began to roll. Hmmm. Hmmm. That's the nature of the kinds of novels I do-I'm outwardly directed into finding out what's going on in the world. It's a great feeling when it happens. I remember one time I was talking to an old farmer and he was remembering that the snow was so high that it drifted over the tops of boxcars in the local rail yard; and as soon as he said- "drifted over the tops of boxcars"-this whole scene came to me with a hobo frozen to death and a little boy finds him and everything. So...you have to be receptive to it, I should say that. You have to be interested in other people, and part of the maturation of the writer is to get beyond your own neurotic compulsions. Most writers - when they begin-are obsessed with themselves and find themselves very interesting. I certainly did. But as you go along you come to realize that you, yourself, are not very interesting compared to the other lives that are out there. It's not that you aren't able to make use of your own perceptions, but there are lives out there. I am a sort of reportorial novelist, and that's my bias. In the end, I'm trying to get a story that's tumbling and heated but also densely and richly expository. 
JDB: Kathryn, I'd like to hear your response to the same question Colin answered with respect to the whole business of plot or structure in the novel-how you move from idea to finished book.

Kathryn: I grew up with my mother's parents, and The Binding Chair began with my desire to discover more about my grandmother, who had an objectively interesting life. She grew up in Shanghai, lived all over the world, and was a temperamental and interesting character in her own right. While I was doing research on China at the turn of the century, and what it was like to live in one of the western communities in China, I came across oral histories of women whose feet were bound-and was derailed from my interest in holding on to my own dead and recreating their lives by the possibility of another, alien life. Ultimately, the book brought the two things together, but the main character turned out to be the Chinese woman, someone completely out of my own understanding, somebody whom I had to pursue-

JDB: In an imaginative sense-

Kathryn: Exactly. So I think that my grandmother's history, while interesting to me, was not quite alien enough, and I had to have somebody to chase through the text; and it turned out to be this Chinese woman. In The Seal Wife, I started out working with my grandfather's life. My grandfather was in Alaska around 1915 and was in Anchorage when Anchorage was created from nothing. It was a town that grew up overnight to house railroad workers when they were building the Alaska railway. My grandfather's been dead for fifteen years. He was a major presence in my life, and embarking on this whole territory is a way of keeping him close to me. It answers an emotional need. My grandfather's first wife was a woman who sang in a tent theater. They projected silent films and during reel changes, in order to provide some sort of auditory experience, she sang. It's a very romantic story, you know. He went to the movies, he heard this woman who had a wonderful voice, and he fell in love with her and married her. So it's a nice story, one that offers a bunch of possibilities. When I began the book, I thought that that was going to be it.

Over the last couple of years I've been going to speech therapy with my son every week. He's just finished, but twice a week for two 
years we went to speech therapy, and while that was something that was of no interest to me beforehand, I began to think about what an interesting thing it is to teach someone to speak better-and how communication, and to be able to communicate in a fluent way, is such a huge thing for a human being. So I ended up doing research on speech therapy, not knowing what I would do with it, but I was interested. And while I was looking into speech therapy I learned a curious fact about stutterers. (Our son does not stutter actually.) Many people who stutter can sing fluently. So suddenly the singer stutters. She can sing, but she can't speak. So the writing, you see, is beginning to pull these things together. As it happens, once I get the guy who is based on my grandfather up to Alaska-before he meets the woman who's going to be his wife-he has a compelling affair with an enigmatic Aleut woman who doesn't speak at all. Now having written that earlier passage, the Aleut woman has become a lot more interesting to me than the woman my grandfather ended up marrying and she's going to have to return. So, again, there is this figure who is alien and who I have to sort of chase down through a thicket of quasi-historical, biographical stuff. None of this is apparent to me when I begin.

JDB: It's interesting to me, Kathryn, that you start from an autobiographical impulse, really, and Colin starts from some information that he's attached to or from a real person, but not necessarily a relative. Then you follow that down through research and story, but you're still making it up as you go along. I mean, both of you are making it up as you go along, and you seem to feel that that's an important part of the process, that you can't just think the story out in advance, do an outline, and follow it through-because that would take the excitement out of it.

Colin: And the discovery out of it. I have students sometimes who say, "I want to write a story that proves a woman should have the right to an abortion." Or: "I want to write a story that shows there should be greater class equality in the United States." My reaction is: "So what?" That's an idea-that's a lecture. I mean this is a commonplace among novelists. If you want lectures, go to church. If you start with any sort of preconceived notion of what the book is or what the message is, or how it ends-if you finish it, if you fin- 
ish it-it's probably going to be dead. This applies to short stories too, I think. Chances are you might not finish it because you know the ending already! So why do it? Why go through it? Why dream it? Why live it? It's much more interesting if you submit to these processes of creation which are semi-conscious, unconscious, and highly conscious at the same time, alternately. That's what a writer spends so many years trying to develop, this mechanism of high awareness about language and human beings and form, and also this ability to dilate and relax and submit to this creative process. It's exhausting. There's almost nothing as exhausting as writing a book, believe it or not. It's not just writing. And then to do it again and again, and to try to arrange your life so that you have the conditions to do it over again. It's hard actually. I don't want to say that in a self-aggrandizing way; I'm trying to say it in a way so that those young writers out there who are serious about this and want to keep going will know: you should expect this to be hard. It's hard Year One and it's hard Year Twenty.

Kathryn: Speaking about what you were saying earlier-I think it's in "The Moronic Inferno," an essay by Martin Amis about the second-novel doldrums, where he says, more or less, "Woe to the writer of the second novel because he or she is in danger of falling prey to An Idea." Writing a novel is not an intellectual process. It calls upon your mind and your intellect, and yet it's not primarily intellectual. It's an unconscious process, and that level of self-consciousness that can kick in after the first novel can be daunting. You know, you wrote the first novel and you didn't really know what you were doing. You were just sitting there, and nobody was waiting for it. Then you get to the second novel and it's like, "What's it about? My God, what's it about? I don't know. It better be about something! I guess it should be about...abortion rights-that's serious." Then you take off, and you've killed it from the outset because of the bogus need for some sort of message....

JDB: I've been wanting to ask Kathryn about the writing of memoirs and about a decision you must have made at some point to call The Kiss a memoir instead of calling it a novel and changing the names. Was that a decision you made on your own, or did you 
consult with other people, and are you glad now that you made the decision you did?

Kathryn: Absolutely glad. Thicker than Water was my first novel, very autobiographical, as first novels sometimes tend to be; then there were two novels that followed that; then I returned to the story that I had novelized because from the moment I finished the first novel I resented having novelized the story. I felt that I had betrayed it and betrayed my own story by turning it into fiction and by dampening it. So when I sat down to write it as memoir, as nonfiction, there was no question that that was how it would be presented-because now I was going to try to do it the right way, or better than I had done it before.

Colin: You had more tools available to you.

Kathryn: Definitely, and I had the guts to do it-as nonfiction-that I didn't have before. I gave myself permission, and we gave me permission too, which was a different issue, or a separate but related issue. Colin has spoken about the writer as transgressor, someone who uses what he or she needs, whether it's right or whether it's wrong. That's something that we both believe and that we give each other permission to do. Writing is an amoral process-it takes what it needs-and everything is permitted. That ethos was part of what allowed me to conceive the story as nonfiction.

JDB: Writing may be amoral in practice, but don't you trust that the process itself is inherently moral at some fundamental level, once it is complete?

Colin: Of course. Absolutely. But art has its own way of seeing.

Kathryn: I've always liked Susan Sontag's remarks on this subject: "The moral pleasure peculiar to art is not the pleasure of approving of acts or disapproving of them. The moral pleasure in art, as well as the moral service that art performs, consists in the intelligent gratification of consciousness." Also Flannery O'Connor's: "James said the morality of a work of fiction depended on the felt life that was in it..." 
JDB: So, Kathryn, do you feel as if you're in a different camp now, because some of your work is in a different part of the library? There seems to be a burgeoning memoir world out there, and a burgeoning marketplace. Was there a difference in the reception of that book because it was a memoir?

Kathryn: Yeah, definitely. It certainly pissed people off in a way that I had never experienced before [Laughter].

JDB: Did it sell more copies?

Kathryn: I imagine it did. Sure it did.

Colin: Many more.

Kathryn: Although I don't know how many more. You know, about the time the book came out, of course, there was a huge storm in a teacup about the "memoir versus the novel," and the memoir was perhaps going to eclipse the novel. I feel the dividing line is between good writing and bad writing. I think the line between memoir and novel has always been incredibly grey. There have been many novels that you read and you understand that they are the truth, but their writers for one reason or another have chosen to call them novels. There are certainly many memoirs that have a fictional quality to them, and you can perceive that as a reader as well. I don't have a conception of two camps inside my head, so I don't feel I've moved over really. I've written a number of shorter personal essays as well-there are rewards to both forms. I think Mary Gordon put it nicely when she said that the great advantage to fiction is that you get to choose the ending you like. You don't get that with nonfiction, and a lot of nonfiction is about how to approach or how to tell the story with the bad ending....

JDB: Kathryn: Did you meet Colin at Iowa?

Kathryn: I did.

JDB: What was that like? 
Kathryn: What was that like-uhhh? I was in the lounge by my mailbox and Colin walked in and said, "Would you like to have lunch?" And I said, "Okay." And he said, "How about next Tuesday?" and I said, "Okay." Then he stood there for a while, and then he said, "Well, aren't you going to write it down?" [Laughter.] And I said, "Okay." [Laughter.]

JDB: You were very cooperative.

Kathryn: I was thinking, "Who is this guy?" So I got out my planner and I wrote it down-while he watched - then after he saw that I had written it down, he moved off down the corridor. And we had lunch, and I moved in four days later.

JDB: Now let's hear that same story from your point of view, Colin. How did you know she was there? How did you arrive at the decision to ask her to lunch?

Colin: I don't know-you get old enough, you start to fall in love for the right reasons. There was this fascinating person I had to be with.

Kathryn: You know, we passed by one another on a number of occasions before then-a party at Bob Shacochis's house and a couple of other functions. I gave a reading of a short story I had written, and Colin came up to me afterwards and corrected one of my sentences or something [Laughter].

Colin: I thought she was just very fascinating.

JDB: Did you get in the habit of reading each other's books and giving advice? And do you do it now?

Colin: Yes.

Kathryn: We do.

JDB: So you each have a live-in editor essentially? 
Kathryn and Colin: Yeah.

JDB: That's terrific, I would think.

Colin: And we both will do a little line editing, as is necessary, for each other. I tend to be-because I'm an egomaniac/freak-I tend to scribble all over hers and write things like, "I don't believe it," or "Come on," or something. She is more quietly devastating in her comments [Kathryn laughs]. But, yeah, we read each other's work and make use of each other's heads, I think, very purposefully.

Kathryn: We have separate strengths, so we can fill in some gaps for each other. Colin is much better at thinking in a logical, orderly manner than I am-

Colin: And you're very helpful at talking to me about the motivations of characters, why they would do what they would do.

JDB: What about the marketplace? What would you do if you were a young writer now who had just finished the manuscript of a novel and wanted to get it published?

Kathryn: The first thing is it's a very people-oriented business and you should make use of whatever relationships you have. If you know a writer who is published whose agent is willing to look at new work-you need to have a chain of people who are going to help you get your work wherever it's going to go. That doesn't mean just looking up a random name in Literary Marketplace. It needs people to shepherd it along.

Colin: You need an agent. The situation is that there are sixty thousand books published in America every year, more or less, and the number of first novels published every year is not dissimilar from the number of people who are becoming professional athletes. It's on the same order of magnitude-it's a couple of hundred. So you see what kind of competition is involved. There are thousands and thousands of people writing novels out there, and somehow-if your book is good-it has to swim through this enormous universe of other stuff and find somebody. Maybe that means being pushy; it 
certainly means being resilient. I spent five years on a book between the ages of twenty-two and twenty-seven that was rejected by fifteen publishers. In retrospect, it was a great gift....

JDB: Only fifteen!

Colin: I gave up on it, and it was a learning book, a training-wheel book; and that experience is very typical. Just as important as learning to find people, to find an agent, and so on, is to learn to deal with rejection and to have resiliency and to stand in there and take your shots as a young writer. The world's not waiting for you. The world is not interested. The world has other things to do. The world has grass to mow, movies to watch, and babies to pick up at daycare centers. That said, however, if you are terrific, the world gets very interested and would like to meet you and invite you out to parties and ply you with alcohol and hope that you're charming. You gotta stand in there and go at it. Most writers who've accomplished anything tend to fail upwards. They've been rejected a great deal, and they've just stayed with it and worked and worked. That didn't happen to you [speaking to Kathryn]. You were....

Kathryn: Charmed.

Colin: You were charmed. Angels came down and plucked her and discovered her. I went the hard road.

Kathryn: Right, but neither story illustrates the truth of publishing. Because publishing is this weird, fey business. It's not a meritocracy. The books that are published are not necessarily the best books. The best books are not the ones that are on the best-seller lists. There are a lot of bad books being published. In fact, working in publishing was one thing that was really important to me as a writer because I had thought of publishing as being this Oz-like edifice, this great castle with unscalable walls. Who knew what was on the other side? There was the lonely writer submitting the pages on this side of the moat, and who knew what happened to them once they got inside? And who were the people who made all those decisions? Well, I was hired by a publishing company. I became one of the people who made the decisions, and I saw that a lot of the 
stuff they were publishing was not great. I worked on other writers' work and thought, "I can do this. In fact, that thing I have at home is better than this." So it was a process of demystification that was incredibly useful. It's not St. Peter up in heaven, picking among the good and the bad. It's a bunch of fallible people who sometimes make inspired choices and decisions and sometimes make really dopey choices and decisions, and good books are published and bad books are published. Being inside, I could see that it was just a business, like selling apples. This one has a bruise. This one tastes really good. We're selling all of them, but not all of them are perfect. Ultimately I found my agent through working in publishing, and it went smoothly from there. But the process of having it demystified for me was key.

Colin: The moment of demystification for me came as a result of taking a bus from Philadelphia to Iowa City before I was a student there. I got off the bus and went straight to the University of Iowa library, where the master's degree theses of the writers in the Writers' Workshop were housed, and I looked up John Irving's thesis, which was called Setting Free the Bears. It was his first novel, and I knew that before The World According to Garp John Irving had published three novels that had disappeared, quite unjustly, and sunk like stones. I had liked The World According to Garp a great deal, and I realized that the first pages of his first novel were there, so I looked it up. It was typewriting in those days, okay? So here was this page, and there was typing on it-typing-real typing-and I'm sure Irving had been the guy who typed it. They were the first pages of a book. You could go and get what was now a paperback and you could compare and it was the same first words, and I was looking at the words and I thought, "Gee, that's a sentence that I could probably write." I didn't presume to think that I could write all those sentences, in that order, and be as engaging and entertaining as he was, but that was a moment of demystification. When something is demystified, not only do you realize something about the thing you've been thinking about but also you realize something about yourself. You are maybe the person you had dreamt yourself to be. 